\section{Renata Štefančič}

Osnovna šola Vojke Šmuc Izola

renata.stefancic@guest.arnes.si
Zbornik povzetkov strokovne konference Spodbujanje učinkovitega učenja, Koper, 26. avgust 2020

Abstracts of the Professional Conference Developing Effective Learning, Koper, 26 August 2020

\section{Veččutno učenje o zeliščih}

Na naši podružnični šoli se zavedamo pomembnosti zelišč, zato smo se odločili zelišča bolj vključiti v pouk, in sicer zelišča z našega vrta. Organizirali smo Dan sivke, ko so učenci z uporabo različnih čutil spoznali to opojno rastlino, ki je prinesla svežino $v$ našo šolo. Šivali smo kokoške za sproščanje in za premagovanje stresa, za dišavo ali za igro. Zelišča smo uporabljali tudi pri branju pravljic. Enkrat tedensko smo se pridružili čarovnici Lenčki in njenim gozdnim prijateljem na razburljivem popotovanju po svetu zelišč. Vsak učenec je po prebrani pravljici lahko povonjal zeliščno kapljico, ki je imela vsaka svoje ime. Znanje zelišč smo uporabili tudi pri pripravljanju različnih jedi in napitkov. $V$ času šolanja na daljavo smo projekt na temo zelišč nadaljevali. Učenci so doma ustvarjali jedi z uporabo zelišč, zbirali recepte, si jih izmenjevali in tako je nastala knjižica receptov. Tako so učenci urili svoje ročne spretnosti in bili pri tem zelo ustvarjalni. Pripomogli so k skrbi za svoje zdravje in zdravje svoje družine, kar je v sedanjem času zelo pomembno. Različne dejavnosti na osnovi zelišč so otrokom ponudile priložnost za izkustveno učenje in za učenje $v$ naravi. Učence smo preko aktivnosti ne le ozaveščali o ekološki vzgoji sadik, temveč jih tudi navajali na potrpežljivost, timsko delo in sodelovanje.

Ključne besede: veččutno učenje, vrt, zelišča, branje pravljic, šolanje na daljavo

\section{Mulitisensory Learning about Herbs}

At our school we are aware of the importance of herbs, so we decided to include more herbs from our garden in the lessons We organised Lavender Day, when students got to know this intoxicating plant using different senses, which brought freshness to our school. We sewed hens to relax and to overcome stress, for fragrance or for play. We also used herbs while we were reading fairy tales. Once a week, we joined the Lenčka witch and her forest friends on an exciting journey through the world of herbs. Each student was able to smell a herbal drop in a circle after reading the fairy tale, each with its own name. We used the knowledge of herbs in the preparation of various dishes and drinks. During distance learning, we continued the project on the topic of herbs. Pupils created dishes at home using herbs, collected recipes, exchanged them, and so a recipe book was created. The students practiced their manual skills and were very creative in doing so. They have helped to take care of their health and the health of their family, which is very important at the present time. Various herbal activities offered children the opportunity for experiential learning and for learning in nature. Through the activities, we not only made the students aware of the organic cultivation of seeds, but also introduced them to patience, teamwork and cooperation.

Key words: multisensory learning, garden, herbs, reading fairy tales, distance learning 